\title{
Pornography and the Violent Offender: Importance of Finding the Offender's Pornography Stash
}

\section{Scott Allen Johnson*}

Licensed Psychologist, Minneapolis, USA

*Corresponding author: Scott Allen Johnson, Licensed Psychologist, Minneapolis, USA, Tel: 612-2693628; E-mail: scott@forensicconsultation.org

Received date: February 12, 2014, Accepted date: May 20, 2014, Published date: May 23, 2014

Copyright: @ 2014 Johnson SA, This is an open-access article distributed under the terms of the Creative Commons Attribution License, which permits unrestricted use, distribution, and reproduction in any medium, provided the original author and source are credited.

\begin{abstract}
When investigating violent offenses including domestic abuse and sexual offenses, it is important to search for and seize the offender's pornography stash. Pornography use has been correlated with both physical and sexual violence and even with general criminality. The pornography represents the offender's preferred sexual preference and violent fantasies, which in turn strongly relate to the offender's violent behavior. Although the pornography does not cause the offender to act out, it contributes to the offender's fantasy which in turn relates to the offender's choice of behavior.
\end{abstract}

Keywords: Pornography; Violent behavior; Sexual fantasies

\section{Pornography and Fantasies}

Pornography offers a playground for sexual and violent fantasies to be thought about, perfected, masturbated to, and eventually acted-out. Hazelwood and Warren [1] indicate that sexual fantasies are an important component of sexual crimes. Fantasies serve an important role for the sexual offender, helping to influence the offender's choice of physical, sexual and verbal interaction with the victim, and the offender's preferred sexual acts and rituals. Several authors have indicated that fantasy alone is not satisfactory and that there tends to be a progressive desire to put the fantasy into actual behavior [2-5].

A sense of sexual entitlement paired with use of pornography may lead to coercive and forced sexual contact [6]. Men who have a sense of entitlement and believe that they deserve sex are likely to be frustrated when women resist their sexual behavior and may resort to the use of force to gain sexual contact [6-9]. Men who frequently use pornography tended report to report engaging in sexually coercive behavior [9].

Several researchers $[10,11]$ found a similarity between the content of sexual fantasies and the actual crime. In addition, [12] found that coercive sexual fantasies were related to a sexual preference for physical violence measured phallometrically, which would suggest that the violent behavior of both batterers and sex offenders are impacted by coercive sexual fantasies. Reviewing the pornography collection allows the investigator to see the fantasies that guided an actual offense and the fantasies that may well guide a future offense. The pornography collection offers insight into the offender's thinking, fantasies, and sexual and violent preference.

Prentky et al. [3] indicated that once the restraints for inhibiting the acting out of the fantasy are gone, the individual is likely to progress to acting out the fantasy and will continue to progressively reenact the fantasy in "trial runs" until the fantasy has been acted out as close to perfect as possible [13].

Prentky and Knight [14] indicated that the degree of deviant sexual arousal may be related to both the frequency of offending and to the amount of violence in offenses [14]. Preference for deviant sexual arousal may be implied by the type of pornographic material the offender views and possesses. Over time, the offender generally becomes more diverse in the type of pornography viewed, and the preferred pornography tends to become more deviant and aggressive in nature. As a result of repeated viewings, the offenders themselves assume a more deviant and aggressive nature. Imagine then how a batterer or sexual offender begins their criminal career with minimal physical aggression, but escalates over time to more deviant and violent behavior [15].

Subsequent violent behavior is then a form of reenacting the deviant sexual fantasies. Prentky and Knight [14] go on to state that detailed studies [16,17] found that the onset of repetitive sexually aggressive behavior coincided with the first appearance of rape fantasies and that these repetitive offenders were also characterized by a high incidence of paraphilias. It is hypothesized that the offender continues to "stage" or practice his fantasy, and the unsuccessful match between the reality of his attempts and the richness of his fantasies contributes to reoffending. Pornography provides the fuel and content of the offender's sexual fantasies.

From an expert's view, who better than a serial rapist to explain the role of pornography and fantasy in sexual violence? Osanka and Johann (1989) reported an interview that Dr. Dobson conducted with Ted Bundy in which Bundy stated:

"My experience with pornography that deals on a violent level with sexuality is that once you become addicted to it and I look at this as a kind of addiction- I would keep looking for more potent, more explicit, more graphic kinds of materials. Until you reach the point where the pornography only goes so far. You reach that jumping-off point where you begin to wonder is maybe actually doing it will give you that which is beyond just reading about it or looking at it."

It is no surprise that people tend to choose the kind of pornography that relates to their sexual preference. If in fact the content of the pornography was offensive to the offender, they would cease use of it. The fact that the sexual offender and domestic batterer tend to become increasingly more sexually preoccupied and invest more time in the viewing of pornographic material suggests an acceptance of the 
degrading and violent theme portrayed in the pornographic material. This preference and acceptance of the content and themes of the pornography also suggest and support certain clinical diagnosis. In fact, those with child pornography related offenses were found to meet the diagnosis for pedophilia even without a history of actually engaging in touch/contact offenses against children [18,19].

Bergen and Bukovec [20] found that over $50 \%$ of the male batterers involved in their study indicated that they have committed rape or sexual assault. Specifically, $14 \%$ of the male partners and $28 \%$ of the husbands used physical force. Approximately $6 \%$ forced their partner to view pornography and $4 \%$ forced their partner to reenact what was seen in the pornography.

Check [21] found that both sexually violent pornography and nonviolent dehumanizing pornography have antisocial effects on the viewer. Repeated exposure to either sexually violent pornography or non-violent dehumanizing pornography increased men's self-reported proclivity for rape and forced sex acts [21].

In 1984, Malamuth and Donnerstein provided some interestingly powerful research about the impact of pornography on the violent offender. There appears to be a direct causal relationship between exposure to aggressive pornography and violence against women [22-27]. Zillman and Bryant [28] found that after massive exposure to pornographic materials, men found pornography less offensive and objectionable. Some researchers argue that it is the aggressive images in the pornography and perhaps not the sexual explicit pictures that encourage violence and rape [29-31]. Research has shown a consistent relationship between exposure to pornographic material and sexually aggressive attitudes and behaviors [32-34].

In addition, massive exposure to pornography significantly increased men's sexual callousness toward women. Some findings provided by Hazelwood (1998) suggest that: 1) 61\% of serial killers (not necessarily sexual murders) used and/or had pornography collections; and 2) at least $90 \%$ of pedophiles used and/or had pornography collections. Regular pornography users very likely experience frustration and are more likely to be unaccepting of a partner refusing their sexual demands [9]. Both violent and nonviolent pornographic material appear to strengthen the relationship between sexually aggressive attitudes and behavior in men, although the relationship is strongest for violent pornography [33,35].

Having a pornography collection implies at least some degree of preoccupation with pornography as well as an investment in the collection. Anecdotally, this author has found that the majority of cases of sexual offenders and physical abusers regularly used some form of pornography.

\section{Why Search for or Review the Offender's Pornography Collection?}

First and perhaps most important is that the vast majority of abusers and sexual offenders have a pornography collection. From a review of the offender's pornography collection the investigator can better understand 1) the offender's personality; 2) the needs the offender acts out/attempts to meet through the offense behavior; 3 ) what the offender would like to do to their victim/s; and 4) the offender's sexual preferences. If the investigator does not find and seize the offender's pornography, valuable information is lost.

Sexual offenders also create their own pornography and I have found that some sexual offenders modify the pornography they posses, cut-and-pasting additional photos to their magazines, and several who included pictures of their victim(s) in their collection as well as one who videotaped a rape onto a commercial bought pornography tape (taping over what was originally on the tape). The information lost from not reviewing the offender's pornography collection can be significant.

This is understandable in that people are more likely to view pornography that is of interest to them versus pornography that they have less arousal or interest in. Engaging in child pornography related offenses appears to justify the diagnosis of pedophilia even without having actually engaged in a sexual contact offense against a child. Child pornography related offenses may include taking or possessing sexually explicit photos or videos of children or possession of or viewing of photos/videos of children engaged in sexual acts. For the diagnosis of pedophilia, DSM-IV (APA, 2000) criteria met would involve:

Recurrent, intense sexual fantasies, urges, or behaviors involving sexual activity with a prepubescent child/ren occurring over at least a 6-month period (evident by the child pornography viewing history, amount of time spent collecting and viewing and probably masturbating to the child pornography, as well as the money invested)

The person has acted out on these sexual urges (e.g., "acted out" includes: has viewed the child pornography, probably has masturbated to the child pornography, has collected the child pornography); the sexual urges or fantasies have caused marked distress or interpersonal difficulty (the child pornography user likely has anxiety about getting caught, has to keep their material secret, and likely experiences difficulty engaging in age-appropriate activities, may experience shame or depression about their sexual arousal to children and use of child pornography). And the person is of course over age 18.

Those who had child pornography offenses and a history of other criminal activities were more likely to reoffend versus those without involvement in other criminal activity [36]. This is understandable because those engaged in varied criminal activity (those who are criminally versatile) are likely more impulsive and can continue to offend in a variety of contexts. Seto and Eke go on to state that those offenders who had a history of sexually offending involving contact with the victim were the most likely to sexually reoffend. Therefore, possessing child pornography appears to be sufficient to meet the diagnostic category of Pedophilia. That is how powerful pornography and child pornography can be. Other sources have found that approximately one-third of child pornography offenders have a criminal history involving sexual offenses with children [37]. In another study, Seto and Eke [37] found that almost 25\% of their sample of child pornography offenders had a prior contact sexual offense involving a child.

As I have stated on numerous occasions, when men masturbate to pornography, they reinforce the negative aspects being portrayed in the pornography. For example, that the expressions on the faces of the women in pictures and videos often are clearly negative, that is, the women appear fearful, crying, pleading to be freed, etc [38]. In addition, the sexual positions and the stories portrayed in the pornography reinforce dangerous and misogynous views of women, views that support and encourage sexual violence and domestic abuse. These men become more prone to act-out with their sexual partners what they see and read about in pornography. Pornography use may even become part of the couple's sexual behavior, using the pornography as a precursor to being sexual with each other. Granted, 
not all users of pornography will become violent or engage in sexually abusive or assaultive behavior. However, domestic batterers and sexual offenders tend to spend significant amounts of time viewing pornography, collecting pornography, and becoming preoccupied with pornography. The vast majority of sexual offenders and domestic batterers I have forensically assessed have had pornography collections and admitted to viewing pornography hours per week. To summarize, although the use of pornography in general may not encourage or result in harm to anyone, violent offenders and sexual offenders consistently spend more time viewing and make a significant investment in pornography.

The problem that exists here are serious. As the offenders increase their use of pornography, and increase the amount of time masturbating to the pornography and they are likely to develop unrealistic expectations of what their sexual partners should be willing to engage in, and without discussion or exception. The use of pornography creates a wonderful fantasy based set of sexual and power expectations. In addition, the more frequently the offender uses pornography, the more likely the offender begins to experience difficulties in relating to others. The pornography may become preferred and may begin to replace real people in the offender's life.

\section{Summary}

So what have we learned from the research? Many professionals tend to minimize the important role pornography plays in physically and sexually violent offenses. This is frustrating given that the research literature has demonstrated time and time again how pornography supports sexual offenders' fantasy which in turn encourages violent behavior. More recent research correlates pornography use to physical batterers as well. Pornography tends to influence the user to become numb to the victim's safety and well-being and offers a playground for fantasy and experimentation of violent, manipulative, and harmful sexual conduct towards both children and adults. Pornography is certainly a strong component that can inspire deviant behavior. In addition, there appears to be a strong correlation between engaging in domestic abuse and sexual abuse, often engaging in both types of violence against one's [38-40]. The sexual offender utilizes pornography to fantasize about meeting their needs as well as to help define preferences that can often lead to more deviant and violent sexual offense behavior. Men are at high risk for engaging in forced sexual behavior when their use of pornographic material has instilled and reinforced attitudes involving women as sex objects [9]. Importantly, Simons et al. [10] found that messages in sexually explicit material are more powerful than lessons learned from the family or society, indicating that frequent use of pornographic material tends to taint appropriate moral and social development.

I want to end with a caveat about pornography in general. I am not condemning pornography nor suggesting that people not view it. There are certainly those who will view and use pornography that will never engage in deviant or violent behavior. What percentage of pornography users never experience negative impact from viewing pornography is difficult to estimate. This article focused on how pornography may inspire more deviant thinking and behavior especially for the physically aggressive offender and sexual offender.

\section{References}

1. Hazelwood RR, Warren JL (2009) The relevance of fantasy in serial sexual crime investigations. In Hazelwood RR and Burgess AW (Eds.),
Practical aspects of rape investigation: A multidisciplinary approach (4th edn) (55-64). Boca Rotan, FL: CRC Press.

2. MacCulloch MJ, Snowden PR, Wood PJ, Mills HE (1983) Sadistic fantasy, sadistic behaviour and offending. Br J Psychiatry 143: 20-29.

3. Prentky RA, Burgess AW, Rokous F, Lee A, Hartman C, et al. (1989) The presumptive role of fantasy in serial sexual homicide. Am J Psychiatry 146: 887-891.

4. Ressler RK, Burgess AW, Douglas JE (1988) Sexual homicide: Patterns and motives. New York: The Free Press.

5. Schlesinger LB (2000) Serial homicide: Sadism, fantasy, and a compulsion to kill. In LB Schlesinger (Ed.), Serial offenders: Current thought, recent findings. Boca Rotan, FL: CRC Press, 3-22.

6. Baumeister RF, Catanese KR, Wallace HM (2002) Conquest by force: A narcissistic reactance theory of rape and sexual coercion. Review of General Psychology 6: 92-135.

7. Beech AR, Ward T, Fisher D (2006) The identification of sexual and violent motivations in men who assault women: implication for treatment. J Interpers Violence 21: 1635-1653.

8. Ryan KM (2004) Further evidence for a cognitive component of rape. Aggression and Violent Behavior 9: 579-604.

9. Simons LG, Simons RL, Lei MK, Sutton TE (2012) Exposure to harsh parenting and pornography as explanations for males' sexual coercion and females' sexual victimization. Violence Vict 27: 378-395.

10. Revitch E (1965) Sex murder and the potential sex murderer. Dis NervSyst 26: 640-648.

11. Revitch E (1980) Gynocide and unprovoked attacks on women. Correctional and Social Psychiatry 26: 6-11.

12. Beauregard E, Lussier P, Proulx J (2004) An exploration of developmental factors related to deviant sexual preferences among adult rapists. Sex Abuse 16: 151-161.

13. Prentky RA, Knight RA (1991) Identifying critical dimensions for discriminating among rapists. J Consult ClinPsychol 59: 643-661.

14. Abel GG, Barlow DH, Blanchard EB, Guild D (1977) The components of rapists' sexual arousal. Arch Gen Psychiatry 34: 895-903.

15. Johnson SA (2011) Psychological force in sexual offenses: Forensic and treatment implications. In: Schwartz BK (Eds.), Handbook of Sex Offender Treatment. (chapter 28). Kingston, New Jersey: Civic Research Institute, Inc.

16. Burgess AW, Hazelwood RR, Rokous FE, Hartman CR, Burgess AG (1988) Serial rapists and their victims: reenactment and repetition. Ann N Y AcadSci 528: 277-295.

17. Hazelwood RR, Reboussin R, Warren JI (1989) Serial rape: Correlates of increased aggression and the relationship of offender pleasure to victim resistance. Journal of Interpersonal Violence 4: 65-78.

18. Seto MC, Cantor JM, Blanchard R (2006) Child pornography offenses are a valid diagnostic indicator of pedophilia. J Abnorm Psychol 115: 610-615.

19. Bergen RK, Bukovec $P$ (2006) Men and intimate partner rape: characteristics of men who sexually abuse their partner. J Interpers Violence 21: 1375-1384.

20. Check JVP (1993) The Effects of Violent Pornography, Nonviolent Dehumanizing Pornography, and Erotica: Some Legal Implications from a Canadian Perspective. In: Itzen C (Ed.). Pornography, Women, Violence, and Civil Liberties: A Radical View. New York: Oxford University Press, 350-358.

21. Check JVP, Guloien TH (1989) Reported Proclivity for Coercive Sex Following Exposure to Sexually Violent Pornography, Nonviolent Dehumanizing Pornography, and Erotica. In: Zillman D and Bryant J (Eds.), Pornography: Research Advances and Policy Considerations. Hillsdale, NJ: Erlbaum.

22. Donnerstein E (1984) Pornography: Its effect on violence against women. In: N. Malamuth and E. Donnerstein (Eds.). Pornography and sexual aggression. New York: Academic Press, 53-80. 
Citation: Johnson SA (2014) Pornography and the Violent Offender: Importance of Finding the Offender's Pornography Stash. J Forensic Res 5: 229. doi:10.4172/2157-7145.1000229

Page 4 of 4

23. Byrne D, Kelley K (1984) Pornography and sex research. In: Malamuth N and Donnerstein E (Eds.). Pornography and sexual aggression. New York: Academic Press, 1-10.

24. Court J (1984) Sex and violence: A ripple effect. In: Malamuth N and Donnerstein E (Eds.). Pornography and sexual aggression. New York: Academic Press, 141-169.

25. Penrod S and Linz D (1984) Using psychological research on violent pornography to inform legal change. In: Malamuth $\mathrm{N}$ and Donnerstein $\mathrm{E}$ (Eds.). Pornography and sexual aggression. New York: Academic-Press, 246-273.

26. Linz D, Turner C, Hesse B, Penrod S (1984) Bases of liability for injuries produced by media portrayals of violent pornography. In: Malamuth $\mathrm{N}$ and Donnerstein E (Eds.). Pornography and sexual aggression. New York: Academic Press, 274-302.

27. Zillmann D, Bryant J (1984) Effects of massive exposure to pornography. In: Malamuth $\mathrm{N}$ and Donnerstein E (Eds.) Pornography and sexual aggression. New York: Academic Press, 114-137.

28. Zillmann D, Bryant J (1982) Pornography, sexual callousness, and the trivialization of rape. J Commun 32: 10-21.

29. Donnerstein E, Linz D (1986) Mass media sexual violence and male viewers: current theory and research. American Behavioral Scientist 29: 601-618.

30. Donnerstein E, Linz D, Penrod S (1987) The question of Pornography: Research findings and policy implications. New York: Free Press.

31. Boeringer SB (1994) Pornography and sexual aggression: Associations of violent and nonviolent depictions with rape and rape proclivity. Deviant Behavior 15: 289-304.
32. Carroll JS, Padilla-Walker LM, Nelson LJ, Olson CD, Barry CM, et al. (2008) Generation XXX: Pornography acceptance and use among emerging adults. Journal of Adolescent Research 23: 6-30.

33. Vega V, Malamuth NM (2007) Predicting sexual aggression: the role of pornography in the context of general and specific risk factors. Aggress Behav 33: 104-117.

34. Williams KM, Cooper BS, Howell TM, Yuille JC, Paulhus DL (2009) Inferring sexually deviant behavior from corresponding fantasies: The role of personality and pornography consumption. Criminal Justice and Behavior 36:198-222.

35. Hald GM, Malamuth NM, Yuen C (2010) Pornography and attitudes supporting violence against women: revisiting the relationship in nonexperimental studies. Aggress Behav 36: 14-20.

36. Seto MC, Eke AW (2005) The criminal histories and later offending of child pornography offenders. Sex Abuse 17: 201-210.

37. Federal Bureau of Investigation (2002) Operation Candyman press release. Retrieved March 3, 2010.

38. Johnson SA (2007) Physical Abusers and Sexual Offenders: Forensic and Clinical Strategies. Boca Raton, Florida: CRC/Taylor and Francis.

39. Campbell JC, Soeken KL (1999) Forced sex and intimate partner violence: Effects of women's risk and women's health. Violence Against Women 5: 1017-1035.

40. Finkelhor D, Yllo K (1985) License to rape: Sexual abuse of wives. New York: Holt, Rinehart and Winston. 